\title{
Perencanaan Instalasi Pengolahan Air Limbah (IPAL) Domestik Skala Kawasan di Kota Sidoarjo
}

\author{
Kristianus Octavianus M.P.P.N dan Agus Slamet \\ Departemen Teknik Lingkungan, Fakultas Teknik Sipil dan Perencanaan, Institut Teknologi Sepuluh Nopember (ITS) \\ e-mail: suga@its.ac.id
}

\begin{abstract}
Abstrak-Air limbah domestik di Kota Sidoarjo belum dikelola dengan baik, dimana greywater dibuang langsung ke drainase tanpa melalui pengolahan. Sustainable Development Goals (SDGs) harus diwujudkan karena salah satu tujuannya yaitu pengolahan air limbah domestik. Rencana Pembangunan Jangka Menengah Nasional (RPJMN) tahun 2015-2019 juga memiliki target yakni 100: 0 : 100. Lokasi perencanaan adalah Kelurahan Lemahputro dan Kelurahan Sidokare, Kecamatan Sidoarjo Kabupaten Sidoarjo. IPAL Kawasan yang dibangun di Indonesia memang masih belum banyak, dikarenakan belum banyak kesadaran dari masyarakat tentang bahaya dari air limbah domestik. Sehingga dibutuhkan inovasi yang bisa lebih mempengaruhi kesadaran masyarakat. Tujuan dari perencanaan studi ini adalah membuat design IPAL domestik dengan model ABR dan Organica Ecotechnology di Kelurahan Lemahputro dan Kelurahan Sidokare Kecamatan Sidoarjo Kabupaten Sidoarjo. Tahapan perencanaan dimulai dari perizinan, survei lokasi, pengumpulan data, studi literatur, pengolahan data, pembahasan dan kesimpulan. Data yang digunakan dalam perencanaan adalah data primer, berupa kualitas air limbah dan survey kondisi eksisting dan data sekuder yang berupa HSPK Kota Surabaya, data lokasi. Data primer diambil dari pengukuran langsung dilapangan dan pengambilan sampel di kelurahan Lemahputro dan kelurahan Sidokare. Data sekunder diambil dari dinas terkait yaitu PDAM Delta Tirta Kabupaten Sidoarjo, Bappeda Kabupaten Sidoarjo, Kelurahan Lemahputro dan Kelurahan Sidokare. Diameter pipa yang digunakan dalam perencanaan pengembangan SPAL dan IPAL kawasan ini adalah $100 \mathrm{~mm}, 150 \mathrm{~mm}, 200 \mathrm{~mm}$ dan $250 \mathrm{~mm}$. ABR kelurahan Lemahputro diperoleh luas $197,01 \mathrm{~m}^{2}$ dengan 3 buah unit paralel. ABR Kelurahan Sidokare diperoleh luas $206,91 \mathrm{~m}^{2}$ dengan 3 buah unit paralel. Biaya investasi total per KK untuk Cluster 1 adalah Rp 7.800.000 dan Cluster 2 adalah Rp 7.200.000. Biaya retribusi setiap kepala keluarga yang harus dibayar melalui organisasi lingkungan setempat setiap bulannya yaitu sebesar Rp 6.000 Cluster 1 dan Rp 4.000 Cluster 2.
\end{abstract}

Kata Kunci-ABR, Air Limbah, IPAL, Organica Ecotechnology, Sidoarjo.

\section{PENDAHULUAN}

ALAH satu masalah utama yang dihadapi oleh $\checkmark$ pemukiman penduduk terutama di daerah perkotaan adalah masalah pencemaran lingkungan yang ditimbulkan oleh pembuangan air limbah yang tidak tertangani dengan baik. Sumber penghasil limbah cair terbesar di negara ini adalah dari hasil aktivitas rumah tangga. Limbah cair domestik adalah air yang telah dipergunakan dan berasal dari rumah tangga atau pemukiman termasuk di dalamnya adalah yang berasal dari kamar mandi, tempat cuci, WC, serta tempat memasak [1]. Pencegahan lingkungan yang tercemar telah diupayakan di beberapa daerah dengan melakukan pengendalian pencemaran melalui UU No 32 tahun 2009 tentang perlindungan dan pengelolaan lingkungan hidup.

Sanitasi lingkungan merupakan salah satu program prioritas Sustainable Development Goals (SDGs). SDGs merupakan sebuah program pengganti Millenium Development Goals (MDGs) yang berlaku pada tahun 2015 - 2030, dimana salah satu dari beberapa tujuannya ialah pengolahan air limbah domestik yang diolah sesuai dengan standar nasional. Sistem pengelolaan air limbah ada dua macam sistem yaitu sistem pembuangan air limbah setempat (on site system) dan pembuangan terpusat (off site system) [2]. Aspek yang penting dalam pengelolaan air limbah adalah sistem penyaluran air limbah (SPAL) dan Instalasi Pengolahan Air Limbah (IPAL).

Kabupaten Sidoarjo merupakan salah satu kabupaten yang lagi berkembang dalam sanitasi Nasional. Sebagai bagian dari pembangunan sanitasi Nasional, Pemerintah Kabupaten Sidoarjo pada Tahun 2010, melalui Badan Perencanaan Pembangunan Daerah (BAPPEDA) telah mengikuti rangkaian kegiatan serta mengambil langkah-langkah strategis dalam Program Nasional Percepatan Pembangaun Sanitasi Permukiman tersebut. Upaya ini telah menempatkan Kabupaten Sidoarjo sebagai salah satu dari 8 Kabupaten/Kota di Provinsi Jawa Timur yang telah ditetapkan pada tahun 2011 untuk melakukan penyusunan Buku Putih Pembangunan Sanitasi dan penyusunan Strategi Sanitasi Kabupaten/Kota (SSK).

SPAL adalah suatu rangkaian bangunan air yang berfungsi untuk mengurangi atau membuang air limbah dari suatu kawasan/lahan baik itu dari rumah tangga maupun kawasan industri. Sistem penyaluran biasanya menggunakan sistem saluran tertutup dengan menggunakan pipa yang berfungsi menyalurkan air limbah tersebut [3]. Langkah yang sebaiknya dilakukan untuk mencapai sanitasi yang lebih baik dan lengkap adalah dengan merencanakan pembangunan IPAL yang nantinya berfungsi untuk melayani penyaluran air limbah domestik di Kelurahan Lemahputro dan Kelurahan Sidokare Kecamatan Sidoarjo Kabupaten Sidoarjo.

IPAL yang digunakan adalah dengan sistem Anaerobic Baffled Reactor (ABR) dengan dikombinasikan Organica Ecotechnology. ABR merupakan pengolahan air limbah secara fisik dan biologis dalam bentuk bak pengendap dengan tujuan untuk meningkatkan effisiensi penyisihan padatan terlarut dan tidak mengendap [4]. Sedangkan Organica Ecotechnology adalah solusi inovatif untuk perbaikan dan daur ulang air limbah. Organica Ecotechnology merupakan pengolahan biologi, karena metode pengolahan ini menggunakan aktivitas biologi dalam penyisihan bahan-bahan pencemar. Mekanisme ini berlagsung secara alamiah dalam badan-badan air yang sehat, seperti danau dan sungai sebagai proses purifikasi [5]. 


\section{METODE PERENCANAAN}

Perencanaan dilakukan dengan mengidentifikasi masalah disekitar daerah yang ingin dijadikan objek perencenaan. Kemudian dilakukan penentuan judul yang tepat dan sesuai dengan persetujuan dosen pembimbing dan berdasarkan lokasi yang diinginkan. Pada perencanaan ini dilakukan perizinan kepada Badan Kesatuan Bangsa dan Politik (Bakesbangpol) Provinsi Jawa Timur, Badan Kesatuan Bangsa dan Politik (Bakesbangpol) Kabupaten Sidoarjo, Badan Perencanaan Pembangunan Daerah (BAPPEDA) Kabupaten Sidoarjo, Perusahaan Daerah Air Minum (PDAM) Delta Tirta Kabupaten Sidoarjo, Kelurahan Lemahputro dan Kelurahan Sidokare, Kecamatan Sidoarjo, Kabupaten Sidoarjo. Kemudian dilakukan survei lokasi dan pengumpulan data dengan tujuan untuk proses analisis dan pengolahan data sehingga dapat memberikan hasil, kesimpulan, dan rekomendasi yang tepat dan baik bagi pihak permukiman. Teori yang akan digunakan adalah teori dalam perencanaan baik pengolahan dan unit IPAL, teori penelitian dari tiap parameter air limbah, dan teori cara mengevaluasi hasil uji sampel.

Perencanaan ini dilakukan ini dilakukan dari bulan Januari sampai Juni tahun 2017. Selama perencanaan berlangsung, dilakukan uji parameter BOD, COD, TSS, Minyak dan Lemak, Amoniak, Total Coliform sebanyak 4 sampel. Kemudian dilakukan pengolahan data dan analisis, dengan aspek yang digunakan adalah aspek teknis dan aspek finansial. Metode yang digunakan adalah metode pengolahan secara biologi yaitu ABR dengan kombinasi Organica Ecotechnology. Kemudian dilakukan perhitungan hasil dan pembahasan yang terdiri dari beberapa perhitungan yaitu: kualitas air limbah IPAL, perhitungan persentase removal unit alternatif, perencanaan perhitungan dimensi dari alternatif desain menggunakan ABR dengan kombinasi Organica Ecotechnology, perhitungan rancangan angaran biaya yang dibutuhkan dalam pembangunan alternatif desain, dan pembuatan gambar teknik desain unit.

\section{HASIL DAN PEMBAHASAN}

\section{A. Perencanaan Sistem Penyaluran Air Limbah}

Daerah pelayanan Sistem Penyaluran Air Limbah (SPAL) pada perencanaan ini meliputi 2 Kelurahan. Kedua Kelurahan tersebut akan dibagi 2 cluster yang didasarkan pada tata letak perkotaan. Data yang diperoleh adalah jumlah Kepala Keluarga (KK), yaitu untuk kawasan Kelurahan Lemahputro sebanyak 2165 KK dan Kelurahan Sidokare ini sebanyak 3939 KK sehingga jumlah total $6104 \mathrm{KK}$. Jumlah anggota keluarga dalam $1 \mathrm{KK}$ adalah 5 orang.

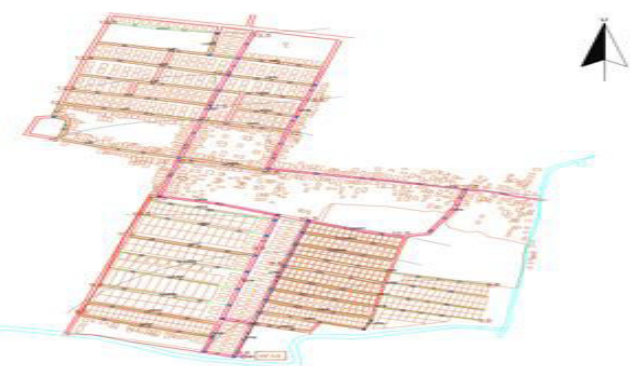

Gambar 1. Peta SPAL Cluster 1 (Lemahputro).

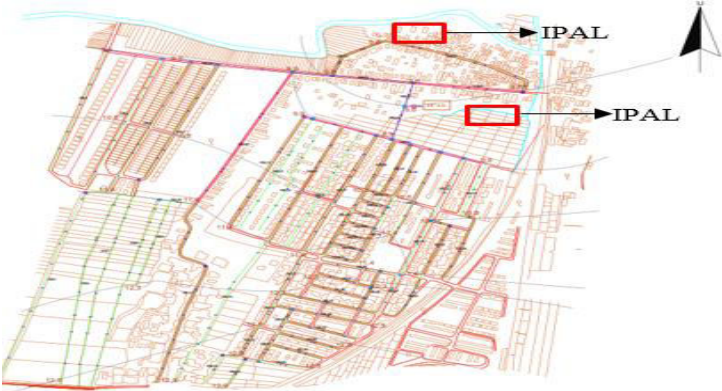

Gambar 2. Peta SPAL Cluster 2 (Sidokare).

Perhitungan debit air limbah diperoleh setelah mengetahui rata-rata penggunaan air bersih yang diketahui melalui data sekunder PDAM "Delta Tirta" Kabupaten Sidoarjo. Metode yang digunakan adalah dengan melihat data air terjual karena pelanggan membayar sesuai dengan debit yang mereka gunakan kemudian dibagi dengan jumlah pelanggan sehingga diperoleh data penggunaan air bersih per Kepala Keluarga. Data penggunaan air bersih akan tersaji pada Tabel 1 berikut ini.

Tabel 1.

Produksi Air Bersih PDAM Delta Tirta Kabupaten Sidoarjo

\begin{tabular}{ccccc}
\hline \hline Tahun & $\begin{array}{c}\text { Produksi Air } \\
\mathrm{m}^{3}\end{array}$ & $\begin{array}{c}\text { Air Terjual } \\
\mathrm{m}^{3}\end{array}$ & $\begin{array}{c}\text { Kehilangan Air } \\
\mathrm{m}^{3}\end{array}$ & $\begin{array}{c}\text { Jumlah } \\
\text { pelanggan } \\
\text { KK }\end{array}$ \\
\hline 2012 & 35.799 .290 & 25.011 .309 & 10.805 .435 & - \\
2013 & 36.376 .915 & 26.076 .690 & 10.300 .225 & - \\
2014 & 39.213 .914 & 26.907 .046 & 12.306 .868 & 119.055 \\
2015 & 41.402 .490 & 28.901 .878 & 12.500 .612 & 133.191 \\
2016 & 42.355 .290 & 30.949 .694 & 11.405 .596 & 133.609 \\
\hline \hline
\end{tabular}

Sumber: PDAM Delta Tirta Kab. Sidoarjo [6]

Dari data yang diperoleh, diambil data yang paling besar dan terbaru yaitu tahun 2016 dengan jumlah air terjual sebesar $30.949 .694 \mathrm{~m}^{3}$ dan jumlah pelanggan sebesar 133.609 KK. Q domestik air bersih 2016 adalah 231.643,7 L/ KK.Tahun. Jika 1 Kepala Keluarga terdapat 5 orang, maka diperoleh debit air bersih per orang adalah 126,92 L/orang.hari

Asumsi presentase air limbah yang mencapai saluran air limbah berada pada kisaran $70-80 \%$ dari penggunaan air bersih [7]. Pada perencanaan ini diambil presentase sebesar 80\%, maka diperoleh hasil sebagai berikut:

$$
>\mathrm{Q} \text { ave air limbah }=126,92 \mathrm{~L} / \text { orang.hari } \mathrm{x} 80 \%
$$$$
=102 \mathrm{~L} / \text { orang.hari }
$$

Diameter pipa yang digunakan pada perencanaan ini adalah 100 mm, 150 mm dan 200 mm untuk Kelurahan Lemahputro. Sedangkan untuk Kelurahan Sidokare menggunakan diameter pipa $100 \mathrm{~mm}, 150 \mathrm{~mm}, 200 \mathrm{~mm}$, dan $250 \mathrm{~mm}$. Sedangkan 
untuk perencanaan ini ada 4 jenis manhole yang digunakan yaitu Manhole lurus, Manhole belok, Manhole pertigaan, Manhole perempatan

\section{B. Perencanaan Instalasi Pengolahan Air Limbah}

Pada pembahasan diambil contoh untuk cluster 1 . Anaerobic Baffled Reactor (ABR) pada cluster 1 direncanakan dibangun 3 unit IPAL ABR yang diletakkan secara pararel dengan dimensi yang sama, maka $Q$ setiap unitnya dapat dihitung:

$$
\begin{aligned}
\mathrm{Q} \text { peak } & =1.425,24 / 3 \text { unit } \\
& =404,9 \mathrm{~m}^{3} / \mathrm{hari} \\
& =404.900 \mathrm{~L} / \mathrm{hari}
\end{aligned}
$$

Sedangkan kualitas air limbah diperoleh dari pengujian effluent air limbah pada Kelurahan Lemahputro dan Kelurahan Sidokare. Sampel dilakukan pengujian di Laboratorium Teknologi Pengolahan Air Teknik Lingkungan ITS.

Tabel 2.

Kualitas Air limbah

\begin{tabular}{cccc}
\hline \hline Parameter & Satuan & Konsentrasi Awal & Baku Mutu \\
\hline $\mathrm{pH}$ & - & 6,95 & $6-9$ \\
$\mathrm{TSS}$ & $\mathrm{mg} / \mathrm{L}$ & 210 & 30 \\
$\mathrm{COD}$ & $\mathrm{mg} / \mathrm{L}$ & 268 & 100 \\
BOD & $\mathrm{mg} / \mathrm{L}$ & 162 & 30 \\
Rasio & - & 0,6 & - \\
BOD/COD & & 20 & 5 \\
Minyak \& & $\mathrm{mg} / \mathrm{L}$ & 48,57 & 10 \\
lemak & $\mathrm{mg} / \mathrm{L}$ & $22 \times 10^{8}$ & 3000 \\
Amonia & $\mathrm{MPN} / 100$ & $\mathrm{~mL}$ & \\
Total & Coliform & \multicolumn{2}{c}{ mL }
\end{tabular}

Waktu detensi untuk zona pengendapan $A B R$ yaitu 3 jam sehingga diperoleh effisensi removal TSS $=64 \%, \mathrm{BOD}=38 \%$ dan $\mathrm{COD}=38 \%$. ABR terdiri dari ruang settling, digesting dan ruang $A B R$ sebanyak 4 kompartemen. Dimensi ruang settling dan digesting yaitu panjang 7,3 m, lebar 3,3 m dan tinggi 3,4 m. Dimensi ruang ABR yaitu panjang total 12,6 m, lebar 3,3 $\mathrm{m}$ dan tinggi 3,4 m dengan memiliki total 4 kompartemen.

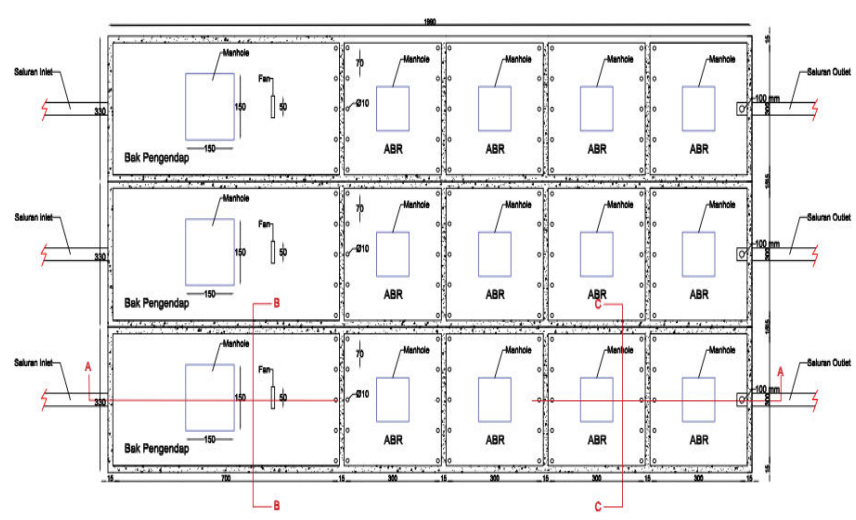

Gambar 3. Denah ABR Hasil Perencanaan Cluster 1

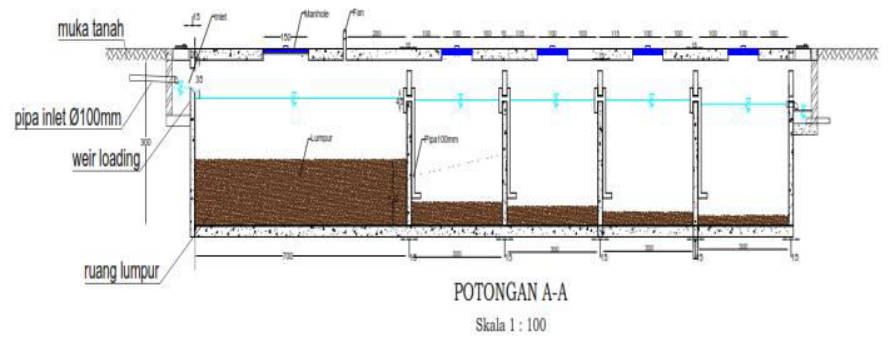

Gambar 4. Potongan A-A ABR Cluster 1.

Effluent ABR masih perlu ditingkatkan kualitasnya, Organica direncanakan untuk meningkatkan kualitas effluent $A B R$ khususnya membantu mengurangi amoniak dan bakteri coliform. Direncanakan 1 buah unit untuk setiap clusternya dengan dimensi panjang $10 \mathrm{~m}$, lebar $10 \mathrm{~m}$, dan tinggi $3 \mathrm{~m}$.

Bakteri coliform atau pathogen adalah bakteri yang hidup pada kondisi anaerob sehingga ketika diberikan oksigen dengan bantuan diffuser atau pada kondisi aerob maka coliform akan mati. Bakteri coliform tidak bisa hidup ketika diberikan sinar UV atau sinar matahari. Penyisihan bakteri coliform menggunakan pendekatan coliform $(\mathrm{Kb})$ dengan waktu detensi dan suhu. Suhu (T) organica yaitu $25^{\prime}$ dengan waktu detensi 5 jam.

Hasil akhir effluent yang diolah dengan Unit IPAL ABR dan Organica untuk Cluster 1 dan 2 disajikan pada tabel 3.

Tabel 3.

Effluent Air Limbah Domestik Cluster 1 dan 2

\begin{tabular}{ccccc}
\hline \hline Parameter & Satuan & Effluent ABR & $\begin{array}{l}\text { Effluent } \\
\text { Organica }\end{array}$ & Baku Mutu \\
\hline TSS & $\mathrm{mg} / \mathrm{L}$ & 30 & 7,1 & 30 \\
COD & $\mathrm{mg} / \mathrm{L}$ & 59,8 & 32,2 & 100 \\
BOD & $\mathrm{mg} / \mathrm{L}$ & 29 & 14,9 & 30 \\
Minyak \& & $\mathrm{mg} / \mathrm{L}$ & 1 & - & 5 \\
lemak & $\mathrm{mg} / \mathrm{L}$ & 48,57 & 0,7 & 10 \\
Amonia & $\mathrm{MPN} /$ & $22 \times 10^{8}$ & - & 3000 \\
Total & $100 \mathrm{~mL}$ & & & \\
Coliform & & & & \\
\hline \hline
\end{tabular}

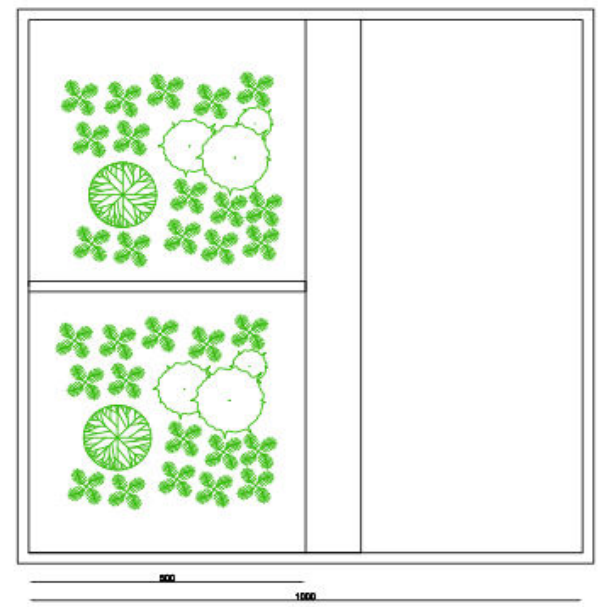

Gambar 5. Denah Organica. 


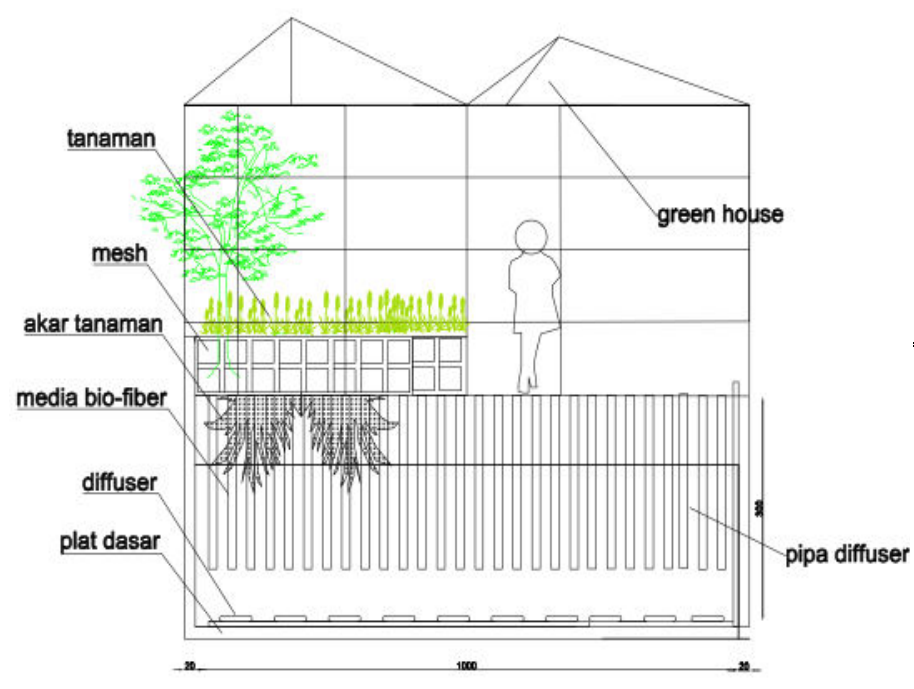

Gambar 6. Potongan Organica.

Unit proses pengolahan air limbah Anaerobic Baffled Reactor dengan kombinasi Organica Ecotechnology yang dipilih karena murah dalam operasional dan perawatannya serta memiliki efisiensi yang cukup tinggi. Sistem IPAL yang digunakan dari segi kualitas pengolahan mampu menghasilkan effluent dibawah baku mutu PERMEN LHK 68 Tahun 2016 untuk TSS, BOD, COD, Minyak dan Lemak, Amonia dan Total Coliform.

\section{Bill Of Quantity $(B O Q)$ dan Rencana Anggaran Biaya (RAB)}

BOQ adalah perincian jumlah dari seluruh peralatan dan perkerjaan yang dibutuhkan di dalam perencanaan. RAB adalah biaya yang diperlukan dalam pengadaan peralatan dan biaya pembayaran tenaga kerja. Perhitungan rencana anggaran biaya pada perencanaan ini menggunakan HSPK Kota Surabaya Tahun 2016.

Tabel 4.

Total RAB SPAL dan IPAL per Kepala Keluarga

\begin{tabular}{ccccc}
\hline \hline Cluster & $\begin{array}{c}\text { SPAL } \\
\mathrm{Rp}\end{array}$ & $\begin{array}{c}\text { IPAL } \\
\mathrm{Rp}\end{array}$ & $\begin{array}{c}\text { Total } \\
\mathrm{Rp}\end{array}$ & $\begin{array}{c}\text { investasi per } \\
\mathrm{KK}\end{array}$ \\
\hline \multirow{2}{*}{1} & 2.740 .577 .424 & 441.469 .946 & 16.846 .319 .455 & $7.781 .209,91$ \\
2 & 3.038 .545 .464 & 484.389 .295 & 28.098 .885 .497 & $7.133 .507,36$ \\
Total & 5.779 .122 .889 & 925.859 .241 & 44.945 .204 .952 & $7.363 .238,03$ \\
\hline \hline
\end{tabular}

\section{Operasi dan Pemeliharaan}

Dalam pengoperasian dan pemeliharaan tentunya dibutuhkan biaya, maka pengguna yaitu masyarakat diwajibkan berpartisipasi melalui biaya retribusi yang dikelola oleh organisasi lingkungan yang telah didirikan. Masyarakat merupakan subjek utama sehingga dibebani biaya retribusi, disisi lain biaya retribusi bertujuan agar masyarakat mempunyai rasa memiliki sehingga timbul kesadaran dan kepedulian, tentunya dengan kemampuan ekonomi dari masyarakat pengguna.
Hasil perhitungan pengeluran dana operasi dan pemeliharaan jaringan SPAL dan IPAL akan menjadi iuran warga per KK yang akan tersaji pada Tabel 5 .

Tabel 5.

Biaya Retribusi per Kepala Keluarga

\begin{tabular}{ccccc}
\hline \hline & & Jumlah & Biaya & \\
Cluster & Kelurahan & KK & Retribusi & Iuran Warga (KK) \\
\hline 1 & Lemahputro & 2165 & 12.149 .167 & $5.611,62$ \\
2 & Sidokare & 3939 & 12.149 .167 & $3.084,33$ \\
\hline \hline
\end{tabular}

\section{KESIMPULAN}

Kesimpulan hasil perencanaan:

1. Perencanaan SPAL dan IPAL

a. Sistem SPAL untuk Kelurahan Lemahputro sepanjang $8.632 \mathrm{~m}$ dengan diameter $100 \mathrm{~mm}, 150 \mathrm{~mm}$ dan $200 \mathrm{~mm}$. Sedangkan sistem SPAL untuk Kelurahan Sidokare sepanjang $13.241 \mathrm{~m}$ dengan diameter pipa yaitu $100 \mathrm{~mm}$, $150 \mathrm{~mm}, 200 \mathrm{~mm}$, dan $250 \mathrm{~mm}$.

b. IPAL untuk semua lokasi direncanakan 3 unit ABR dipasang secara paralel, dengan luas lahan kelurahan Lemahputro $=197,01 \mathrm{~m}^{2}$ dan Kelurahan Sidokare $=$ $206,91 \mathrm{~m}^{2}$.

c. Efluen hasil perencanaan IPAL dirancang memenuhi baku mutu Permen KLHK No. 68 Tahun 2016.

2. Rencana Anggaran Biaya SPAL dan IPAL

a. Anggaran Biaya total yang dibutuhkan sebesar:

$$
\begin{array}{lll}
- & \text { Cluster I }=\operatorname{Rp} 16.846 .319 .455 \\
\text { - } & \text { Cluster II }=\operatorname{Rp~28.098.885.497~}
\end{array}
$$

b. Biaya retribusi setiap kepala keluarga (KK) yang harus dibayar melalui organisasi lingkungan setempat setiap bulannya yaitu sebesar Rp 6.000 Cluster 1 dan Rp 4.000 Cluster 2.

\section{UCAPAN TERIMA KASIH}

Penulis mengucapkan terimakasih kepada Bakesbangpol Jawa Timur dan Kabupaten Sidoarjo, BAPPEDA Kabupaten Sidoarjo, PDAM Delta Tirta Sidoarjo, Kelurahan Lemahputro dan Kelurahan Sidokare yang telah membantu memberi data dan informasi.

\section{DAFTAR PUSTAKA}

Sugiharto, Dasar-Dasar Pengolahan Air Limbah. Jakarta: Universitas Indonesia Press, 2008.

R. J. Kodoaatie and R. Sjarief, Pengelolaan Sumber Daya Air Terpadu. Yogyakarta: Andi, 2008.

M. Dewiandratika, Sistem Penyaluran Air Limbah. Jakarta: Mutiara, 2002.

A. Morel and S. Diener, "Greywater Management in Low and Middle-Income Countries, Review of Different Treatment Systems for Households or Neighbourhoods," Duebendorf, 2006.

B. Chandra, Pengantar Kesehatan Lingkungan. Jakarta: EGC, 2006. Perusahaan Daerah Air Minum Kabupaten Sidoarjo, "Produksi Air Bersih PDAM Delta Tirta Kabupaten Sidoarjo Tahun 2017," Sidoarjo, 2017.

7] Setiyono, "Desain Perencanaan Instalasi Pengolahan Air Limbah (IPAL) dan Re-use Air di Lingkungan Perhotelan," JAI, vol. 5, no. 2, 2009. 